\title{
Mathematical Modelling of Corrosion Processes of Zinc/Iron roofing sheet in Coastal/Industrial Environment
}

\author{
Awajiogak A. Ujile ${ }^{1}$ and Ehirim O. Emmanuel ${ }^{2}$ \\ Department of Chemical/Petrochemical and Petroleum Engineering \\ Rivers State university of Science and Technology \\ Nkpolu-Oroworukwo, Port Harcourt, Nigeria \\ P.M.B. 5080
}

\begin{abstract}
Mathematical correlation was developed to predict the behaviour of iron roofing sheets on exposure to different environmental conditions. The analytical results from Atomic Absorption Spectroscopy (AAS) of chromium, iron and zinc contents for the locations considered were fed into the developed equation. Corrosion rates were determined by weight loss method and model, and the results from the two methods were in agreement. The predicted rate constants for location A is $0.036 / \mathrm{hr}$, for location B is $0.0174 / \mathrm{hr}$, while location C is 0.000013 . The corrosion rates by weight loss method were $0.51 \mathrm{mpy}$ and $0.221 \mathrm{mpy}$ for locations $\mathrm{A}$ and $\mathrm{B}$ respectively, within the first five years of operations, while the corrosion rate at location $\mathrm{C}$ from $5-10$ years, was $0.0068 \mathrm{mpy}$. These results clearly indicate that corrosion is heavier on locations close to the industrial areas. This also shows the negative impact of industrial activities on the corrodible materials and consequently on the plants and environment.
\end{abstract}

Keywords: - Corrosion rate, Corrosion kinetics and Mathematical modelling

\section{INTRODUCTION}

Corrosion is the degradation of material through environmental interactions. Thermodynamics and kinetics form the basic fundamentals of corrosion. Thermodynamics indicates whether a specific corrosion process is possible while kinetics determine the actual rates of corrosion.

A significant amount of energy is put into a metal when it is extracted from its ores placing it in high energy state. One principle of thermodynamic is that a material seeks the lowest energy state. In other words most metals are thermodynamically unstable and would tend to react with something in their environment (e.g. oxygen, water), in order to reach more stable energy state such as oxide. The process by which metals convert to the lower energy oxides is called corrosion.

Due to the dynamic and variable atmospheric conditions in industrial area of South-Southeast region of Nigeria, the predictions of atmospheric corrosion of metallic materials assume a difficult phenomenon. Experience has shown that roofing materials exposed to highly industrial and humid environment are very susceptible to high corrosion rates. Climatic factors also like rainfall, temperature, relative humidity, sunshine and wind are notoriously known to adversely affect the behaviour and growth of exposed materials and plants $[1,2]$. Atmospheric corrosion of roofing materials has also been done in most temperate regions of the world $[3,4]$. However, less scientific research has been carried out in recent past on atmospheric corrosion of roofing materials in the humid, highly industrial tropical regions of south-southeast where this work was carried out.

A comprehensive study on zinc roofs close to bauxites/alumina plants to ascertain the accusations from communities showed that the plant activities have advert effect on the zinc roofs[5]. The conclusion from the study has shown that the cause of corrosion was not from the plant, but from other factors e.g. quality of galvanized sheet used did not meet the minimum standard required; non-professional manner of storage of the sheets developed 'white rust', the start of corrosion process before installation. Construction materials like corrugated iron roofing sheets when exposed to material environment also tend to revert to lower energy oxide state. Atmospheric corrosion of metallic roofing sheet in building construction in Niger Delta region of Nigeria was examined. This work showed that atmospheric conditions have damaging impact on the corrosion of the roofing sheets [6].

It has been observed in recent times that the grade of roofing sheet used in construction is susceptible to corrosion than those that were used in the 1940s-1950s. Besides the recent advances in industrial activities especially in the oil and gas industries where the atmosphere has been heavily polluted with contaminants and have exacerbated the corrosion rate of roofing sheet of building located in such areas.

The variations of the hydro thermal situation affect the corrosion behaviour of zinc sheeting [7]. During the last 2-6 decades, numerous field and laboratory research programs have been conducted to investigate the corrosion behaviour of zinc under different types of atmospheres, but only few studies related to zinc roofing sheet has 
been carried out [8]. Their work did not consider the effects of industrial pollutants exuded from flare on zinc sheet [9].

Coastal areas are known to have very high salt loadings in the air because of ions that emanate from the sea[10]. The investigation is to develop model equations that could describe the deterioration of active ingredients and formation of corrosion products on iron roofing sheets at the three locations, as shown in figure 1.

The aim of this study is to present a mathematical model that predicts the depreciation of the active ingredients and the rate of corrosion of the roofing sheet on buildings located in industrial/coastal environment. Three locations in Akwa Ibom state of Nigeria were considered in this study: Location A - Industrial/coastal environment, (where flares from oil/gas and salt laden air are predominant); Location B - Only coastal environment; Location $\mathrm{C}$ - Hinterland (where there is no effect of the industrial/coastal impact). This work therefore is to incorporate the industrial activities of oil and gas on zinc roofing sheet.

\section{KINETICS OF THE CORROSION PROCESSES ON IRON ROOFING SHEETS: MATHEMATICAL FORMULATION.}

Air moving across the earth's surface picks up additional loads of substances. In the troposphere, potential air pollutants mix vertically and horizontally and often react with each other or with the components (pollutants) of the atmosphere.

Let us assume ideal mixing of the reaction components and the active protective ingredients in the composition of the zinc roofing sheet. If the reaction components from the atmosphere come into contact with iron roofing sheets (by bulk flow, wind effect or rain effects) whose thickness, $\mathrm{T}$ can be changed at a mass rate of flow $\mathrm{M}$, and is removed from the iron sheet at a mass flow rate $\mathrm{M}_{2}$, then the number of moles of any substance (active protective ingredient) in the roofing sheet will change with time. This change in concentration of the active protective ingredient will result in change in volume (thickness), corrosion and hence deterioration of the roofing sheet, see Figures 1 and 2. Fig 2 shows that at time $t+d t$ the surfaces of the roofing sheet is no longer smooth.

Let the initial concentration of the substance $\mathrm{A}$ in the iron roofing sheet be $\mathrm{C}_{\mathrm{A} 0}$. If the ideal mixing of all components is assumed and achieved on the roofing sheet (taking an elemental cross- section), then the concentration of the substance as it is disposed by rain or wind effect will decrease. Let it be denoted by $\mathrm{C}_{\mathrm{A}}$. The true rate of chemical reaction relative to the substance A could be denoted by $\mathrm{J}$ mathematically as follows: The kinetic process can be represented mathematically by:

$\mathrm{J}=\mathrm{KC}_{\mathrm{A}}{ }^{\mathrm{n}}$

Where $\mathrm{J}=$ the rate of chemical reaction $\left[\mathrm{gmol} / \mathrm{cm}^{3} . \mathrm{sec}\right]$

$\mathrm{C}_{\mathrm{A}}=$ the concentration of the reactants $\left[\mathrm{gmol} / \mathrm{cm}^{3} . \mathrm{sec}\right]$

$\mathrm{K}=$ reaction rate constant $\left[\mathrm{sec}^{-1}\right]$

$\mathrm{n}=$ order of reaction $=1$

The material balance equation for the process can be represented as follows: 


$\left\{\begin{array}{l}\text { change in number of } \\ \text { moles of substance } \\ \text { A in the roofing } \\ \text { sheet per unit time }\end{array}\right\}=\left\{\begin{array}{l}\text { Number of moles } \\ \text { substance A } \\ \text { (active ingredient }) \\ \text { introduced into the } \\ \text { roofing sheet per } \\ \text { unit time }\end{array}\right\}\left\{\begin{array}{l}\text { Number of moles } \\ \text { substance leaving the } \\ \text { roofing sheet by } \\ \text { rain or wind effect } \\ \text { per unit time }\end{array}\right\}$ -

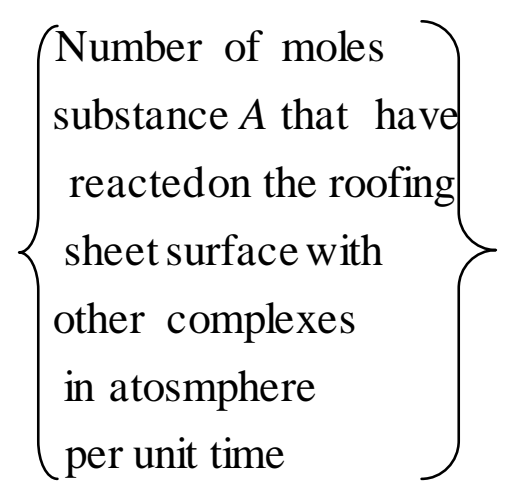

Equation (2) can be represented in mathematical form by inserting the values of the corresponding quantities as follows:

$\frac{d\left(C_{A} S T\right)}{d t}=C_{A 0} \frac{M_{1}}{\rho}-C_{A} \frac{M_{2}}{\rho}-J \frac{M}{\rho}$

Where

$\rho=$ density of the reaction mass $\left[\mathrm{kg} / \mathrm{m}^{3}\right]$

$\mathrm{S}=$ surface area $\left[\mathrm{m}^{2}\right]$

$\mathrm{T}=$ thickness of the roofing sheet $[\mathrm{m}]$

$\mathrm{ST}=$ volume $\left[\mathrm{m}^{3}\right]$

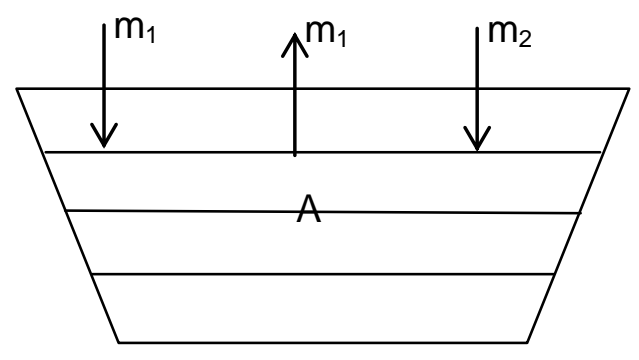

Figure 1: Cross section of roofing sheet at $\mathrm{t}=0$

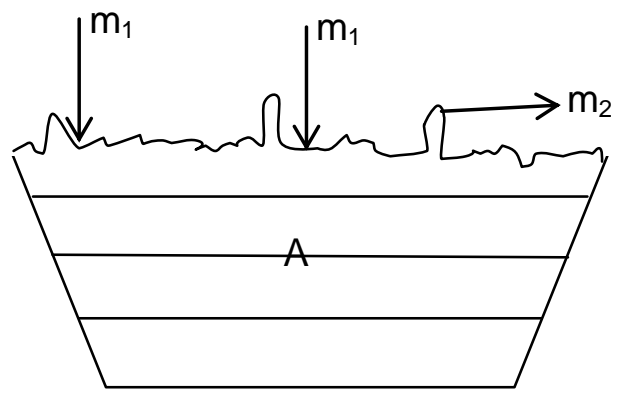

Figure 2: Cross section of roofing sheet at time $t+d t$

Let us denote $\frac{M_{1}}{\rho}=\omega_{1}$ and $\frac{M_{2}}{\rho}=\omega_{2}$

Where $\omega_{1}$ and $\omega_{2}$ are volumetric flow rates at different times $t=0$ and $t=t+d t$, respectively.

Hence equation (3) becomes:

$\frac{d\left(C_{A} V\right)}{d t}=C_{A 0} \omega_{1}-C_{A} \omega_{2}-J V$ 
Equation (4) is the general process model of the dynamic behaviour of components in the iron roofing sheet when in contact with atmospheric pollutants.

Combining equations (3) and (4) for a first order reaction yields:

$$
\frac{d\left(C_{A} V\right]}{d t}+K C_{A} V+C_{A} \omega_{2}=C_{A 0} \omega_{1}
$$

Where $\mathrm{C}_{\mathrm{A}} \mathrm{V}=$ number of moles of components $\mathrm{A}$.

$$
\frac{V d\left(C_{A}\right)}{d t}+C_{A} \frac{d V}{d t}=C_{A 0} \omega_{1}-C_{A} \omega_{2}-K C_{A} V
$$

Assuming, $\omega_{1}=\omega_{2}$, because of the wind effect on contaminants that affect corrosion complexes.

Then equation (6) becomes:

$$
\frac{V d\left(C_{A}\right)}{d t}+C_{A} \frac{d V}{d t}=\omega_{1}\left(C_{A 0}-C_{A}\right)-K C_{A} V
$$

Assuming negligible change in volume, $\mathrm{dv} / \mathrm{dt}=0$;

Equation (7) becomes:

$$
\begin{aligned}
& \frac{V d\left(C_{A}\right)}{d t}+K C_{A} V+\omega_{1} C_{A}=\omega_{1} C_{A 0} \\
& \text { Or } \\
& \frac{d\left(C_{A} D\right.}{d t}+\left(K+\frac{\omega_{1}}{V_{A}}\right) C_{V}=\frac{\omega_{1} C_{A 0}}{V}
\end{aligned}
$$

Equation (9) is the general model of the kinetic corrosion of iron roofing sheet.

Using Euler method, the solution of equation (9) becomes:

$$
C_{A}=\frac{\varpi_{1} C_{A}}{V}\left[1-e^{-\left(K+\frac{\omega_{1}}{V}\right) t}\right]
$$

If a natural logarithm is taken on both sides of equation (10), we have:

$$
\log C_{A}=\log \left[\frac{\omega_{1} C_{A}}{V}\right]+\left(K+\frac{\omega_{1}}{V}\right) t
$$

A plot of the natural logarithm of concentration of the active ingredients against time gave a straight line. The values of $\omega_{1}$ and $\mathrm{K}$ were determined from the intercepts and slope, respectively.

\section{METHODOLOGY}

Figure 1 shows the map of Akwa Ibom state with the location of Esit Urua-A, Ibaka-B, and Ikono-C. The Environmental conditions of these areas, relative humility, ambient temperature, dew point were determined with whirling hydrometer and results obtain as $88 \%-100 \%, 28^{\circ} \mathrm{C}-35^{\circ} \mathrm{C}, 26^{\circ} \mathrm{C}-30^{\circ} \mathrm{C}$, respectively for locations $\mathrm{A}$ and $\mathrm{C}$. For location $\mathrm{C}$, the relative humidity, ambient temperature and dew point were $60 \%$ $90 \%, 28^{\circ} \mathrm{C}-37^{\circ} \mathrm{C}, 25^{\circ} \mathrm{C}-38^{\circ} \mathrm{C}$.

Iron roofing sheet were removed from different roofs depending on age limit under consideration. Usually, one to these pieces of roofing sheet (SWAN BRAND) of $0.15 \mathrm{~mm}$ thickness removed from buildings that were covered in less than one year $(<1) ; 1-5$ years; 5 - 10years; $10-15$ years; and $15-30$ years. This exercise was carried out at the three locations and a new one replaced for the owners. $10 \mathrm{~cm} \times 15 \mathrm{~cm}$ specimen sample from each of the roofing sheets was cut and sent for analysis. The results from Atomic Absorption Spectroscopy (AAS) analysis are shown on tables 1 and 2. The zinc, chromium, iron oxide (rust), sulphate and chloride contents were determined for various periods. 


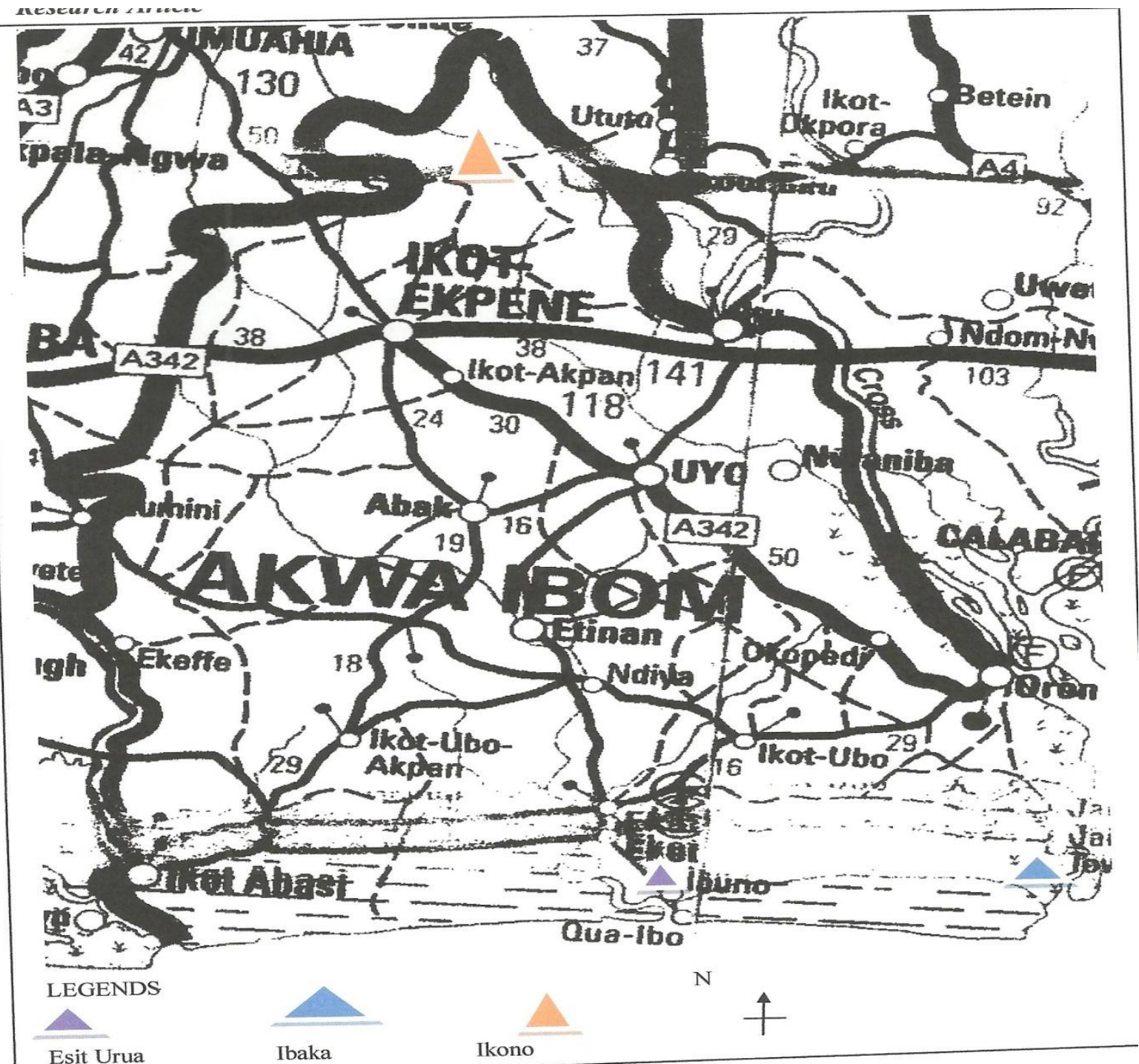

Fig. 3. Map of Akwa Ibom Nigeria showing the locations under consideration

IV. RESULTS AND DISCUSSION

Table1. Concentration levels of active ingredient considered in roofing sheets in the study locations

\begin{tabular}{|c|c|c|c|c|c|c|}
\hline \multirow[b]{2}{*}{$\begin{array}{l}\text { Sample } \\
\text { Location }\end{array}$} & \multirow[b]{2}{*}{$\begin{array}{l}\text { Sample } \\
\text { Identification }\end{array}$} & \multicolumn{2}{|c|}{$\mathrm{g} / 100 \mathrm{~g}$} & \multicolumn{3}{|c|}{$\mathrm{gm} / \mathrm{kg}$} \\
\hline & & Zinc & Chromium & $\begin{array}{l}\text { Ferrous } \\
\text { Oxide }\end{array}$ & Sulphate & Chlorine \\
\hline \multirow{5}{*}{ Esit Urua } & $\mathrm{A}_{11}$ & 6.45 & 0.022 & 32.95 & $<1.0$ & 25 \\
\hline & $\mathrm{A}_{21}$ & \begin{tabular}{|l|}
1.67 \\
\end{tabular} & 0.019 & 31.93 & $<1.0$ & 30 \\
\hline & $\mathrm{A}_{31}$ & \begin{tabular}{|l|}
1.48 \\
\end{tabular} & 0.009 & 30.90 & $<1.0$ & 20 \\
\hline & $\mathrm{A}_{41}$ & \begin{tabular}{|l|}
0.98 \\
\end{tabular} & 0.015 & 26.07 & $<1.0$ & 35 \\
\hline & $\mathrm{A}_{51}$ & \begin{tabular}{|l|}
1.80 \\
\end{tabular} & 0.024 & 22.14 & $<1.0$ & 28 \\
\hline \multirow{5}{*}{ Ibaka } & $\mathrm{B}_{11}$ & \begin{tabular}{|l|}
2.56 \\
\end{tabular} & 0.019 & 26.66 & $<1.0$ & 36 \\
\hline & $\mathrm{B}_{21}$ & 1.56 & 0.013 & 13.97 & $<1.0$ & 52 \\
\hline & $\mathrm{B}_{31}$ & \begin{tabular}{|l|l|}
1.14 \\
\end{tabular} & 0.011 & 14.81 & $<1.0$ & 56 \\
\hline & $\mathrm{B}_{41}$ & \begin{tabular}{|l|}
0.92 \\
\end{tabular} & 0.008 & 15.90 & $<1.0$ & 49 \\
\hline & $\mathrm{B}_{51}$ & 1.25 & 0.014 & 18.61 & $<1.0$ & 46 \\
\hline \multirow{5}{*}{ Ikono } & $\mathrm{C}_{11}$ & \begin{tabular}{|l|}
1.39 \\
\end{tabular} & 0.013 & 15.89 & $<1.0$ & 51 \\
\hline & $\mathrm{C}_{21}$ & 1.43 & 0.014 & 17.37 & $<1.0$ & 49 \\
\hline & $\mathrm{C}_{31}$ & \begin{tabular}{|l|}
2.08 \\
\end{tabular} & 0.021 & 15.59 & $<1.0$ & 45 \\
\hline & $\mathrm{C}_{41}$ & \begin{tabular}{|l|}
1.18 \\
\end{tabular} & 0.015 & 17.60 & $<1.0$ & 40 \\
\hline & $\mathrm{C}_{51}$ & \begin{tabular}{|l|}
1.29 \\
\end{tabular} & 0.024 & 19.47 & $<1.0$ & 38 \\
\hline New zinc & roofing sheet & 10.2 & 0.035 & 41.56 & $<1.0$ & $<10$ \\
\hline
\end{tabular}


Mathematical Modelling of Corrosion Processes of Zinc/Iron roofing sheet in Coastal/Industrial

Table2.0: Estimated Corrosion on Samples of Zinc Coated Steel from the study areas

\begin{tabular}{|c|c|c|c|c|c|c|c|c|}
\hline $\begin{array}{l}\text { Sample } \\
\text { Location }\end{array}$ & $\begin{array}{l}\text { Sample } \\
\text { Identific } \\
\text { ation }\end{array}$ & $\begin{array}{l}\text { Surface } \\
\text { Area } \\
\left(\mathrm{cm}^{2}\right)\end{array}$ & $\begin{array}{l}\text { Surface } \\
\text { Area } \\
\left(\text { inch }^{2}\right)\end{array}$ & $\begin{array}{l}\text { Initial } \\
\text { Weig } \\
\text { ht }(\mathrm{g})\end{array}$ & $\begin{array}{l}\text { Final } \\
\text { Weight } \\
\text { (g) }\end{array}$ & $\begin{array}{l}\text { Weight } \\
\text { Loss }(g)\end{array}$ & $\begin{array}{l}\text { Duratio } \\
\mathrm{n} \\
\text { (years) }\end{array}$ & $\begin{array}{l}\text { Corrosion } \\
\text { rate (mpy) } \\
\text { (wt loss x } \\
\text { 22300)/a.d..t }\end{array}$ \\
\hline \multirow{5}{*}{ Esit Urua } & $\mathrm{A}_{11}$ & 407 & 65.12 & 48 & 35 & 13 & $1-5$ & 0.514 \\
\hline & $\mathrm{A}_{21}$ & 38 & 60.8 & 50 & 48 & 2 & $5-10$ & 0.034 \\
\hline & $A_{31}$ & 220.73 & 35.32 & 55 & 48 & 7 & $10-15$ & 0.1225 \\
\hline & $\mathrm{A}_{41}$ & 364.64 & 58.34 & 50 & 37 & 13 & $15-30$ & 0.091 \\
\hline & $\mathrm{A}_{51}$ & 385.2 & 61.63 & 50 & 48 & 2 & $<1$ & 0.501 \\
\hline \multirow{5}{*}{ Ibaka } & $\mathrm{B}_{11}$ & 363.5 & 58.16 & 40 & 35 & 5 & $1-5$ & 0.2214 \\
\hline & $\mathrm{B}_{21}$ & 208.52 & 33.36 & 30 & 25 & 5 & $5-10$ & 0.1544 \\
\hline & $\mathrm{B}_{31}$ & 208.52 & 33.36 & 30 & 25 & 5 & $10-15$ & 0.093 \\
\hline & $\mathrm{B}_{41}$ & 284.2 & 45.47 & 37.5 & 25 & 12.5 & $15-30$ & 0.0965 \\
\hline & $\mathrm{B}_{51}$ & 418 & 66.88 & 50 & 48 & 2 & $<1$ & 0.462 \\
\hline \multirow{5}{*}{ Ikono } & $\mathrm{C}_{11}$ & 440 & 70.4 & 50 & 50 & 0 & $1-5$ & 0 \\
\hline & $\mathrm{C}_{21}$ & 473 & 75.68 & 50 & 49.5 & 0.5 & $5-10$ & 0.0068 \\
\hline & $\mathrm{C}_{31}$ & 404 & 64.64 & 75 & 74 & 1.0 & $10-15$ & 0.00543 \\
\hline & $\mathrm{C}_{41}$ & 409 & 65.5 & 62.5 & 62 & 0.5 & $15-30$ & 0.00268 \\
\hline & $\mathrm{C}_{51}$ & 517.5 & 82.8 & 55 & 55 & 0 & $<1$ & 0 \\
\hline
\end{tabular}

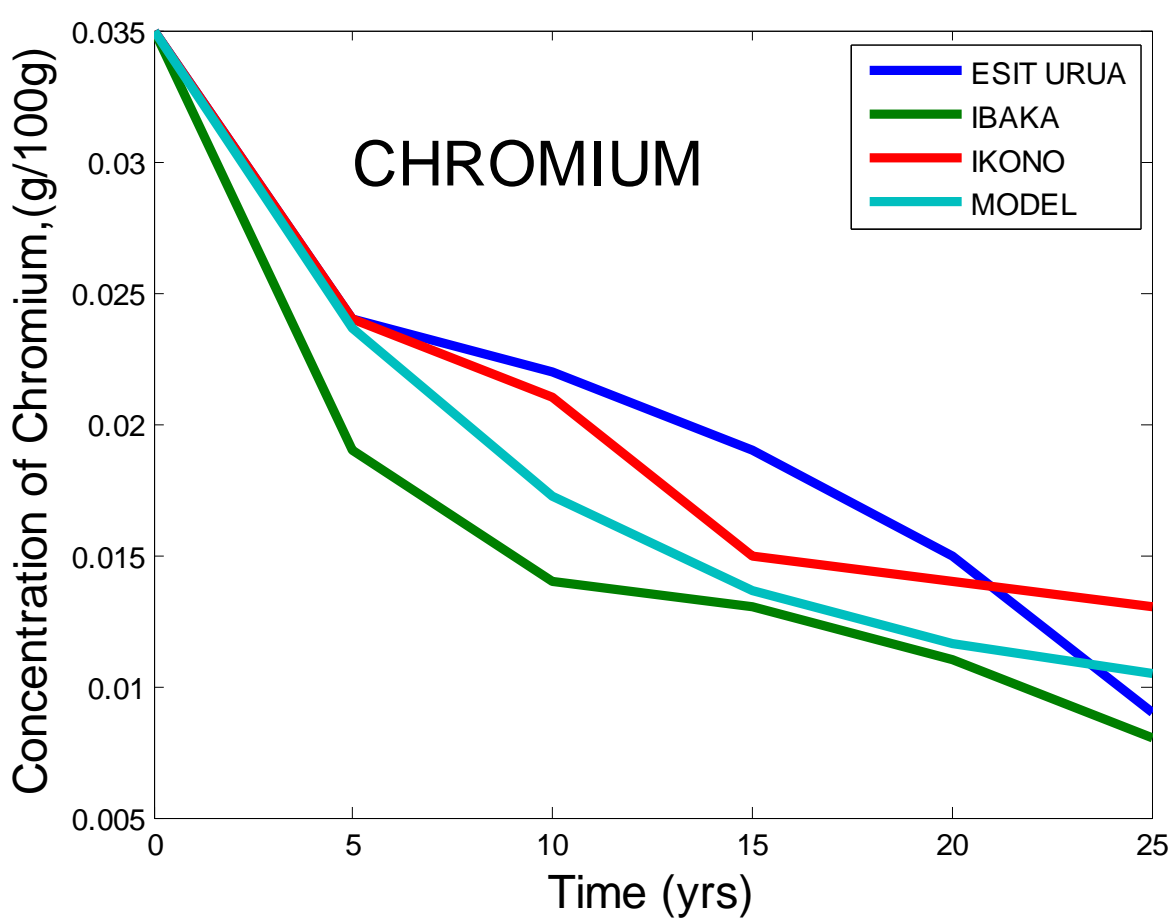

Fig. 4 Chromium depreciation in the three locations: Experimental and Model 


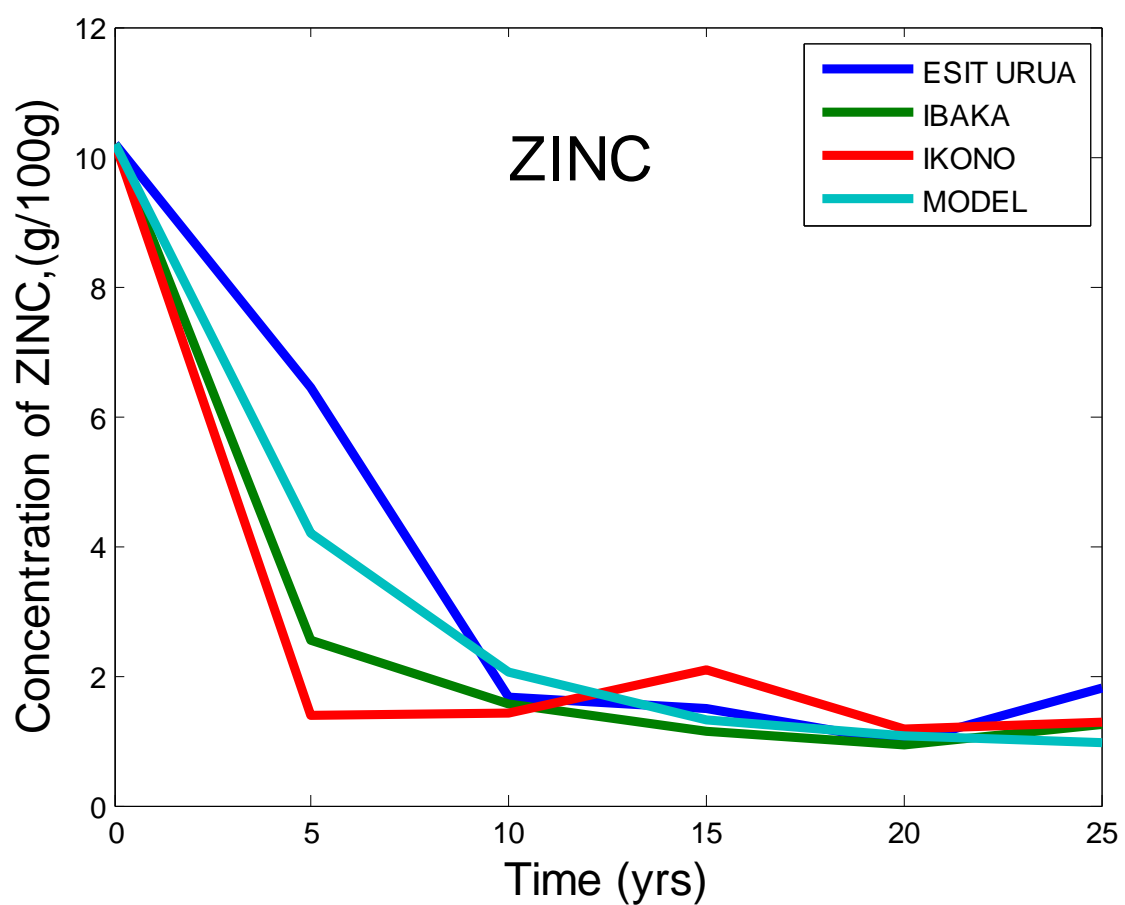

Fig. 5 Zinc depreciation in the three locations: Experimental and Model

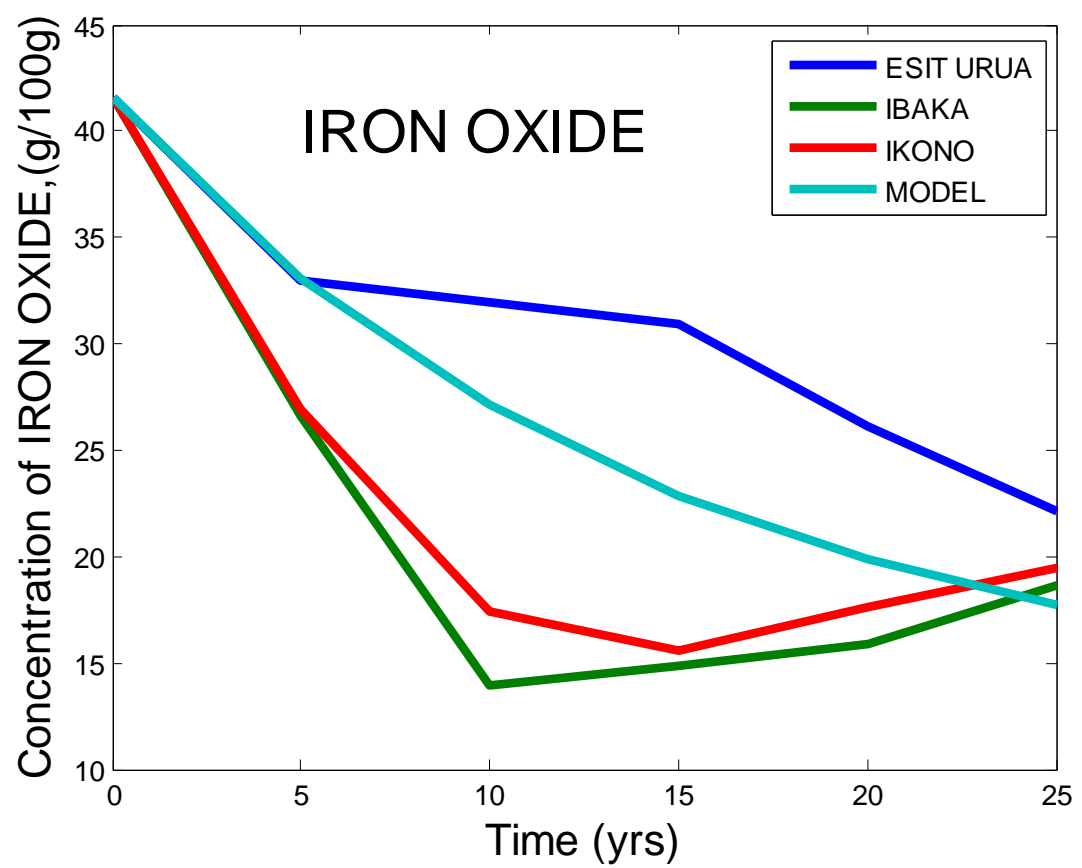

Fig. 6 Iron Oxide depreciation in the three areas considered: Experimental and Model. 


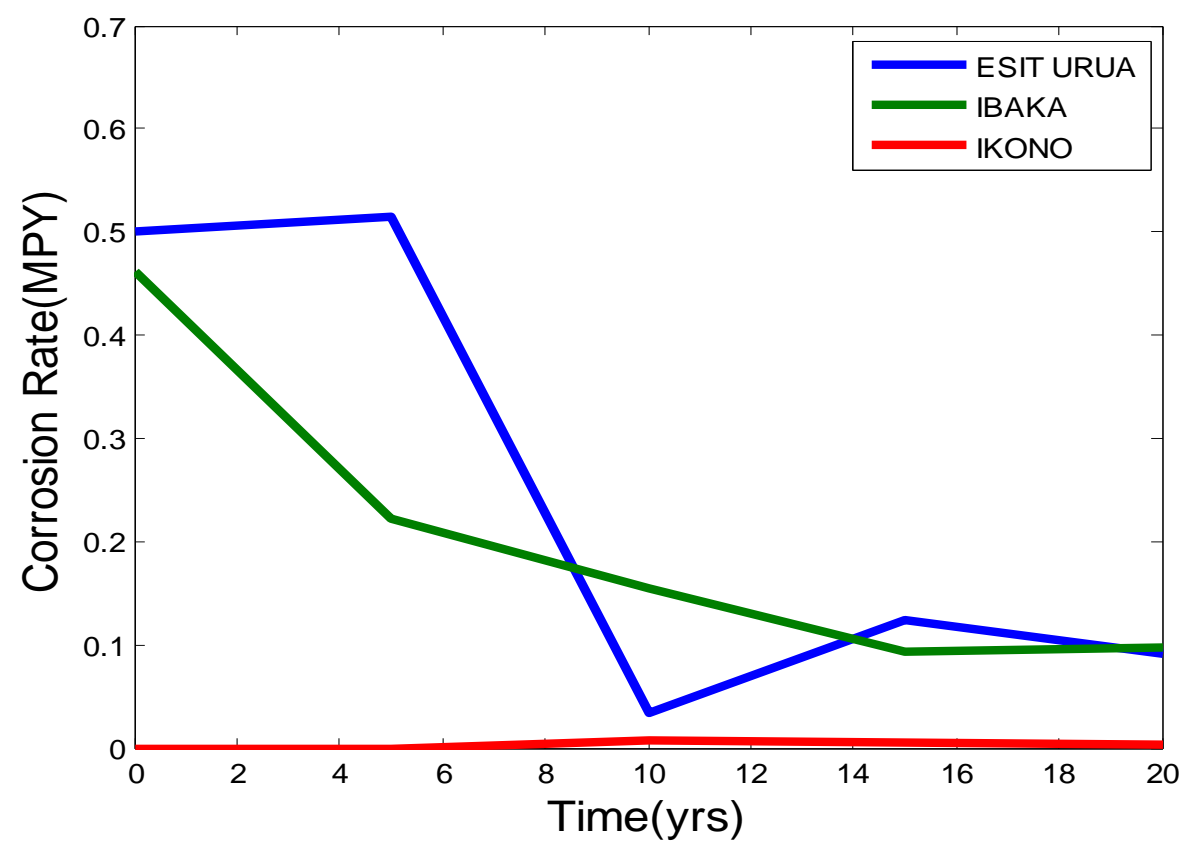

Fig.7 Rates of Corrosion of Zinc coated steel in locations A, B and C

Table 4 shows the depreciation of the active ingredients in the iron roofing sheet. Figures 5-7 are plotted from this table. The results of the simulated model equations for each location are also plotted together with the experimental data. The rates of corrosion in the three different locations are plotted in figure 7.

Fig. 4 shows the depreciation of chromium in the three locations. It can be generally observed that the rate of depreciation is highest within the first five years and decreases gradually with time. This trend is also observed in the model result. This behaviour is due to the fact the material exposed to the industrial flare and coastal factors depreciate faster initially and decreases due to the formation of probably the oxides which retard corrosion rate as the time progressed. From this figure it can be inferred that Ibaka, coastal region, registered the highest corrosion impact while Ikono (hinterland) registered the least. This could be due to the variation in intensities of climatic events and pollutant concentrations from the industries.

Figs. 5 and 6 describe the depreciation of zinc and iron oxide from the roofing sheet in the studied three locations, respectively. As illustrated, the graphs show the same trend as in figure 4. Depreciation rates were high within the first 5 years and decreased with time. The model also shows the same behaviour. The impact of climatic factors was more pronounced on location B, Ibaka. This could be due to the increased pollutant concentrations brought by the wind from industrial flares and also the effect of the heavy rain fall in this region. Another important observation is that Esit Urua, a city situated closet to the plant experienced the most depreciation (globally) in the active elements than Ikono located farthest from the plant. This clearly shows that areas closest to the plants suffer a lot of material damage by corrosion. The above observation is reinforced by the values of the calculated rate constants $\mathrm{K}$, within the first 5 year-period, for the three locations: Esit Urua, $\mathrm{K}$ $=0.036 / \mathrm{hr}$; Ibaka, $\mathrm{K}=0.0174 / \mathrm{hr}$; and Ikono $\mathrm{K}=0.0000137 / \mathrm{hr}$. It is important to note that corrosion impacts on the roofing sheet were noticed to be 0.0068 m.p.y at Ikono from 5-10 years.

Fig. 7 illustrates the estimated corrosion rates on samples of zinc coated steel from the study areas. It can also be observed that corrosion rates are greatest at Esit Urua, closest to the plant location as compared to Ibaka and Ikono farther away from plant operations. This could be the impact of both the climatic factors and industrial activities associated with this region.

\section{CONCLUSION}

The corrosion impact within the first five years of operation was heavier in all the locations under investigation. This investigation has shown clearly that both industrial activities and climatic conditions impact strongly on corrosion of roofing sheets. Statistically, the mathematical model agrees very well with the experimental results, since the coefficient of determination $\mathrm{r}^{2}$ was more than $80 \%$.

We suggest that the flared gases should either be treated or reinjected into the ground to reduce the advert effect of the aerosol on the construction materials. Also roofing materials which can withstand adverse atmospheric conditions should be sort instead of the corrugated iron roofing sheet. 


\section{REFERENCES}

[1] Johnson, E. And Linder, M. (1993). The influence of Industrial acidification in the atmospheric corrosion of zinc. Cape Town: Proceedings of $12^{\text {th }}$ International Corrosion Congress 2, 249-560

[2] Cole IS, Neufeld AK, Kao P, Ganther W, Chitomongkol L Barmornsut C, Hue NV, Bernado S and Purwadaria A (1999). Development of performance verification methods for the durability of metallic components in Tropical Countries. Proceedings of the 11th Asian- Pacific Corrosion Control Conference 92 55-57.

[3] Graedel TE and McGill W (2011). Degradation of materials in the Atmosphere. Environmental Science Technology 1093 - 1100.

[4] Cole I.S., Paterson D. A. and Ganther W. D. (2003). Holistic model for atmospheric corrosion Part - 1 theoretical frame work for production, transportation and deposition of marine salts. Corrosion, Engineering, Science and Technology, 38(2), 129-134.

[5] Kearny NJ (No Date). Corrosion Resistance to Atmospheric Corrosion. http://www.corrosiondoctors.org/Corrosion-Atmospheric/Corrosion-resistance.htm, accessed 14 December 2013.

[6] Obia and Obot (2010). Atmospheric corrosion of metallic roofing sheet in building construction in the Niger Delta region of Nigeria; Journal of Environmental Issues and Agriculture in Developing Countries (2\& 3).

[7] Deans SW and Lee TS (1987). Degradation of metals in the Atmosphere. Philadelphia P. A. American Society for Testing and Materials.

[8] Zheng Y, Wang Z and Zhang F (1991). Influence of acid deposition on atmospheric corrosion of zinc. Journal of Environmental Science, China 3(2) 53-60

[9] Ovri JEO and Iroh M (2013). Corrosion Effect of Gas Flaring On Galvanized Roofing Sheet in Imo State, Nigeria, The International Journal of Engineering and Science (IJES) 2(1) 339-345.

[10] Ujile AA and Ehirim E (2009). Evaluating a technique for solving corrosion process models on oil and gas facilities. Conference Proceedings 4th Annual Corrosion Management Summit. 11- 14 October, 2009, Hilton Abu Dhabi Hotel, Abu Dhabi, United Arab Emirates. 